\title{
Perlindungan Hukum Terhadap Pekerja: Perspektif Tanggung Jawab Konstitusional Negara
}

Syamsul Alam ${ }^{1}$ \& Mohammad Arif

Fakultas Hukum, Universitas Muslim Indonesia

Koresponden, Email: moh.arif.fh@umi.ac.id

\begin{abstract}
ABSTRAK
Kedudukan Hukum Pekerja dan Pengusaha adalah setara. Namun pada penerapannya cenderung menempatkan pengusaha pada posisi yang lebih diuntungkan Mendasari hal tersebut, paper ini bertujuan untuk menganalisis perlindungan hukum terhadap pekerja dari aspek tanggungjawab konstitusional negara. Metode penelitian yang digunakan adalah jenis penelitian dengan Analisis Isi (Content Analysis). Hasil penelitian menunjukkan bahwa Perlindungan hukum terhadap pekerja dimaksudkan untuk menjamin hak-hak dasar dan menjamin kesamaan kesempatan serta perlakuan tanpa diskriminasi atas dasar apapun untuk mewujudkan kesejahteraan pekerja/buruh beserta keluarganya.
\end{abstract}

Kata Kunci: Perlindungan; Hukum; Pekerja; Konstitusional

ABSTRACT

The legal position of workers and entrepreneurs is equal. However, in practice, it tends to put employers in a more advantageous position. Based on this, this paper aims to analyze legal protection for workers from the aspect of state constitutional responsibility. The research method used is a type of research with Content Analysis. The results of the study show that legal protection for workers is intended to guarantee basic rights and guarantee equal opportunity and treatment without discrimination on any basis to realize the welfare of workers / laborers and their families.

Keywords: Protection; Law; Workers; Constitutional 


\section{PENDAHULUAN}

Perlindungan hukum selalu terkait dengan peran dan fungsi hukum sebagai pengatur dan pelindung kepentingan masyarakat (Qamar \& Djanggih, 2017), Bronislaw Malinowski dalam bukunya berjudul Crime and Custom in Savage, mengatakan "bahwa hukum tidak hanya berperan di dalam keadaan-keadaan yang penuh kekerasan dan pertentangan, akan tetapi bahwa hukum juga berperan pada aktivitas sehari-hari (Soeroso, 2008).

Secara konstitusional Negara bertanggungjawab atas perlindungan bagi segenap bangsa Indonesia dan mewujudkan kesejahteraan bagi seluruh rakyat Indonesia (Suhardin, 2012). Didalam entitas yang disebut Negara, kesejahteraan rakyat merupakan hal mutlak, dan salah satu tolak ukur kesejahteraan rakyat adalah kesejahteraan kaum buruh/pekerja (Hendrastomo, 2010). Perlakuan secara adil dan bijaksana dan tanpa diskriminasi atas alasan apapun kepada para pekerja/buruh merupakan cerminan dari keberpihakan Negara dalam hal melindungi buruh/pekerja yang merupakan bagian dari keseluruhan komponen hidup berbangsa dan bernegara (Charda, 2015). Hal ini juga sejalan dengan yang tertuang didalam Pasal 28D ayat (2) Undang-Undang Dasar Negara Republik Indonesia Tahun 1945 (UUD NRI 1945) bahwa : Setiap orang berhak untuk bekerja serta mendapat imbalan dan perlakuan yang adil dan layak dalam hubungan kerja.

Perlindungan hukum terhadap pekerja merupakan pemenuhan hak dasar yang melekat dan dilindungi oleh konstitusi sebagaimana yang diatur dalam Pasal 27 ayat (2) UUD NRI 1945 yang berbunyi “Tiap-tiap warga negara berhak atas pekerjaan dan penghidupan yang layak bagi kemanusiaan”, Pasal 33 ayat (1) yang menyatakan bahwa” Perekonomian disusun sebagai usaha bersama atas kekeluargaan". Perlindungan terhadap pekerja dimaksudkan untuk menjamin hak-hak pekerja dan menjamin kesamaan kesempatan serta perlakuan tanpa adanya diskriminasi atas apapun untuk mewujudkan kesejahteraan pekerja dan keluarganya dengan tetap memperhatikan perkembangan kemajuan dunia usaha dan kepentingan pengusaha. Peraturan perundang-undangan yang terkait dengan perlindungan bagi pekerja yakni Undang-Undang No 13 Tahun 2003 tentang Ketenagakerjaan dan peraturan pelaksana dari perundang-undangan dibidang ketenagakerjaan.

Pertimbangan Undang Undang No. 13 Tahun 2003 tersebut di atas sesuai dengan amanat Pasal 27 ayat (2) Undang Undang Dasar Negara Republik Indonesia Tahun 1945 (UUDNRI 1945), bahwa setiap warga negara berhak atas pekerjaan dan penghidupan yang layak sesuai dengan kemanusiaan. Demikian juga yang ditentukan dalam Pasal 28D ayat (1) UUDNRI 1945, bahwa setiap orang berhak atas pengakuan, jaminan, perlindungan, dan kepastian hukum yang adil serta perlakuan yang sama dihadapan hukum, dan setiap orang berhak untuk bekerja serta mendapat imbalan dan perlakuan yang adil dan layak dalam hubungan kerja sebagaimana penegasan Pasal 28D ayat (2) UUDNRI 1945 (Budiartha, 2016).

Perlindungan hukum bagi pekerja sangat diperlukan mengingat kedudukan pekerja berada pada pihak yang lemah.Perlindungan terhadap pekerja dimaksudkan untuk menjamin terpenuhinya hak-hak dasar pekerja dan menjamin kesamaan kesempatan serta perlakuan tanpa diskriminasi atas dasar apapun untuk mewujudkan kesejahteraan pekerja. Secara teori, dalam hubungan Perburuhan Industrial Pancasila, ada asas hukum yang mengatakan bahwa, buruh dan majikan mempunyai kedudukan yang sejajar.Menurut istilah perburuhan disebut partner kerja. Namun dalam praktiknya, kedudukan keduanya ternyata tidak sejajar. Pengusaha sebagai pemilik modal mempunyai kedudukan yang lebih tinggi dibandingkan 
pekerja. Hal Ini jelas tampak dalam penciptaan berbagai kebijakan dan peraturan perusahaan”. Mengingat kedudukan pekerja yang lebih rendah dari majikan inilah maka perlu campur tangan pemerintah untuk memberikan perlindungan hukum, agar keadilan dalam ketenagakerjaan lebih cepat tercapai (Suyanto \& Nugroho, 2017).

Berdasarkan Badan Pusat Statistik (BPS), Jumlah angkatan kerja di Indonesia pada Februari 2019 mencapai 136,18 juta orang, bertambah sekitar 5,17 juta orang (3,95 persen) dibandingkan angkatan kerja Agustus 2018 sebesar 131,01 juta orang dan bertambah 2,24 juta orang (1,67 persen) dibandingkan angkatan kerja Februari 2018 sebesar 133,94 juta orang. Jumlah penduduk yang bekerja pada Februari 2019 sebesar 129,37 juta orang, bertambah sekitar 5,36 juta orang (4,32 persen) jika dibandingkan dengan keadaan Agustus 2018 (124,01 juta orang), dan bertambah 2,30 juta orang (1,81 persen) jika dibandingkan dengan keadaaan Februari 2018 (127,07 juta orang). Jumlah pengangguran terbuka pada Februari 2019 mencapai 6,82 juta orang, berkurang sekitar 18o ribu orang jika dibandingkan keadaan Agustus 2018 (7,00 juta orang), dan berkurang 50 ribu orang jika dibandingkan dengan keadaan Februari 2018 (6,87 juta orang). Tingkat Pengangguran Terbuka (TPT) di Indonesia pada Februari 2019 mencapai 5,01 persen, mengalami penurunan sebesar 0,33 persen poin dibanding TPT Agustus 2018 (5,34 persen) dan mengalami penurunan sebesar o,12 persen poin dibanding TPT Februari 2018 (5,13 persen). Pada Februari 2019, Tingkat Pengangguran Terbuka (TPT) tertinggi terjadi di Provinsi Jawa Barat, yaitu 7,73 persen, sedangkan TPT terendah terjadi di Provinsi Bali sebesar 1,19 persen (Statistik, 2019).

Kaitannya dengan data tersebut, nasib pekerja di Indonesia ditemukan adanya lemahnya perlindungan hukum bagi pekerja/buruh juga dapat terlihat dari problematika ountsourcing (alih daya). Poblematika outsourching memang cukup bervariasi seiring akselerasi penggunaannya yang semakin marak dalam dunia usaha (Anzar, 2020). Sementara regulasi yang ada belum terlalu memadai untuk mengatur outsourcing yang telah berjalan ditengah kehidupan ekonomi dengan hegemoni kapitalisme financial yang beroperasi melalui dissolution subject yang tidak memandang pekerja/buruh sebagai subjek produksi yang patut dilindungi, melainkan sebagai objek yang bisa di eksploitasi (Saefuloh, 2011).

Hubungan hukum antara buruh/pekerja dengan pengusaha pada kenyataannya bersifat timpang. Hal ini disebabkan posisi buruh yang kurang beruntung dibandingkan dengan posisi pengusaha. Dalam teknis hubungan kerja yang terjadi adalah hubungan subkoordinasi (hubungan vertikal, antara atasan dengan bawahan).

\section{METODE PENELITIAN}

Penelitian hukum yang penulis lakukan termasuk jenis penelitian dengan Analisis Isi (Content Analysis) secara sederhana diartikan sebagai metode untuk mengumpulkan dan menganalisis muatan dari sebuah "teks" (Ahmad, 2018). Teks dapat berupa kata-kata, makna gambar, simbol, gagasan, tema dan bermacam bentuk pesan yang dapat dikomunikasikan. Analisis Isi berusaha memahami data bukan sebagai kumpulan peristiwa fisik, tetapi sebagai gejala simbolik untuk mengungkap makna yang terkadang dalam sebuah teks, dan memperoleh pemahaman terhadap pesan yang direpresentasikan, sesuai tujuannya, maka metode Analisis Isi menjadi pilihan untuk diterapkan pada penelitian yang terkait dengan isi komunikasi dalam sebuah teks. 
Pendekatan yang digunakan dalam penelitian ini adalah pendekatan dilakukan dengan content analisis. Pada penelitian ini akan berupaya untuk mendiskripsikan tentang perlindungan hukum terhadap pekerja dari perspektif tanggungjawab konstitusinal negara.

\section{PEMBAHASAN}

\section{A. Perlindungan Hukum Pekerja Dalam Konstitusi}

Hakikat hukum ketenagakerjaan adalah perlindungan terhadap pekerja, yakni dimaksudkan untuk menjamin hak-hak dasar pekerja/buruh dan menjamin kesempatan serta perlakuan tanpa diskriminasi atas dasar apapun untuk mewujudkan kesejahteraan pekerja/buruh beserta keluarganya dengan tetap memperhatikan perkembangan dunia usaha (Singadimedja, 2020).

Landasan idiil pembangunan ketenagakerjaan adalah berlandaskan pada Pancasila dan UUD NRI 1945, pembangunan ketenagakerjaan dilaksanakan dalam rangka pembangunan manusia Indonesia seutuhnya. Oleh sebab itu, pembangunan ketenagakerjaan prinsipnya harus sesuai dengan asas pembangunan nasional, khususnya demokrasi Pancasila, adil, dan merata. Pembangunan ketenagakerjaan terkait dengan berbagai pihak antara lain pemerintah, pengusaha, dan pekerja/buruh, oleh sebab itu perlu dilaksanakan secara terpadu dalam bentuk kerjasama yang saling mendukung.

Didalam UUD NRI 1945 Pasal 28D ayat (2) : Setiap orang berhak untuk bekerja serta mendapat imbalan dan perlakuan yang adil dan layak dalam hubungan kerja. Pasal ini memberikan semangat keadilan dan kelayakan dalam hubungan kerja terkait dengan imbalan dan perlakuan, yang selanjutnya secara yuridis, diejawantahkan didalam ketentuan Pasal 4 UU Ketenagakerjaan dijelaskan bahwa tujuan hukum ketenagakerjaan adalah :

a. Memberdayakan dan mendayagunakan tenaga kerja secara optimal dan manusiawi. Didalam penjelasan diartikan bahwa pemberdayaan dan pendayagunaan tenaga kerja merupakan suatu kegiatan yang terpadu untuk dapat memberikan kesempatan kerja seluas-luasnya bagi tenaga kerja Indonesia. Melalui pemberdaayaan dan pendayagunaan ini diharapkan tenaga kerja Indonesia dapat berpartisipasi secara optimal dalam pembangunan nasional, namun dengan tetap menjunjung nilai-nilai kemanusiaannya

b. Mewujudkan pemerataan kesempatan kerja dan penyediaan tenaga kerja yang sesuai dengan kebutuhan pembangunan nasional dan daerah. Didalam penjelasan diartikan bahwa pemerataan kesempatan kerja harus diupayakan di seluruh wilayah Negara Kesatuan Republik Indonesia sebagai satu kesatuan pasar kerja dengan memberikan kesempatan yang sama untuk memperoleh pekerjaan bagi seluruh tenaga kerja Indonesia sesuai dengan bakat, minat, dan kemampuannya. Demikian pula pemerataan penempatan tenaga kerja perlu diupayakan agar dapat mengisi kebutuhan di seluruh sektor dan daerah

c. Memberikan perlindungan kepada tenaga kerja dalam mewujudkan kesejahteraan, dan

d. Meningkatkan kesejahteraan tenaga kerja dan keluarganya

Dalam beberapa hal UU Ketenagakerjaan menempatkan pekerja pada posisi yang lemah, yakni sebagai objek hukum, atau dengan kata lain pekerja dalam pengertian orang/manusianya dijadikan sebagai objek perjanjian, padahal hakikatnya pekerja merupakan subjek hukum atau pendukung hak dan kewajiban. Pasal 1 ayat (2) UU Ketenagakerjaan mendefenisikan "tenaga kerja adalah setiap orang yang mampu melakukan 
pekerjaan guna menghasilkan barang dan/atau jasa baik untuk memenuhi kebutuhan sendiri maupun untuk masyarakat”. Hal mendasar yang perlu diperhatikan adalah, pembuat undangundang mendefenisikan tenaga kerja sebagai "orang”, sehingga pihak pengusaha dapat menjadikan "orang" sebagai objek yang diperjanjikan dalam perjanjian kerja, padahal seyogyanya yang menjadi objek perjanjian adalah lebih ditekankan pada potensi dan/atau kemampuan yang dimiliki oleh pekerja sementara pekerja hanyalah sebagai subjek hukum, atau pendukung hak dan kewajiban, yang dalam bahasa UU Ketenagakerjaan Pasal 1 ayat (2) disebutkan "mampu melakukan pekerjaan guna menghasilkan barang dan/atau jasa".

Dengan definisi "tenaga kerja" tersebut maka membuka ruang bagi pengusaha untuk memperlakukan pekerja secara tidak adil dan manusiawi, karena pekerja dianggap sebagai objek hukum dalam perjanjian kerja, maka pemberi kerja berrhak untuk memperlakukan pekerja seenaknya, tanpa memperrhatikan prinsip-prinsip keadilan, secara sederhana dapat dicontohkan Si Fulan (orang/manusia/pekerja) yang memiliki potensi atau kemampuan mengemudikan mobil (tenaga kerja/potensi), dipekerjakan oleh pemberi kerja sebagai sopir diperusahaannya, karena Si Fulan adalah orang/manusia/pekerja, sehingga kedudukannya secara hukum adalah sebagai subjek hukum, sedangkan yang diperjanjikan sebagai objek perjanjian adalah potensi/kemampuan yang dimiliki oleh si fulan sebagai driver, oleh sebab itu pemberi kerja tidak bisa memerintahkan si fulan mengerjakan hal-hal yang tidak termasuk atau diluar dari apa yang diperjanjikan, dalam hal ini adalah tugas dan tanggung jawabnya sebagai driver. Namun apabila berdasar pada defenisi tenaga kerja yang termaktub didalam UU Ketenagakerjaan maka tenaga kerja yang diperjanjikan termasuk orang/manusia/pekerja.

Merujuk pada landasan idiil dari hukum ketenagakerjaan Indonesia adalah Pancasila dan UUD NRI 1945, maka sangat erat keterkaitannya ketika penulis sedikit membahas tentang prinsip keadilan sosial yang tentunya juga dapat dijadikan sebagai landasan filosofis dari lahirnya UU Ketenagakerjaan. Pada alinea ke IV Pembukaan UUD NRI 1945 tertulis : “...susunan Negara Republik Indonesia yang berkedaulatan Rakyat dengan berdasar kepada Ketuhanan Yang Maha Esa, Kemanusiaan yang Adil dan Beradab, Persatuan Indonesia, Kerakyatan yang dipimpin oleh Hikmat Kebijaksanaan dalam Permusyawaratan Perwakilan, serta dengan mewujudkan suatu keadilan sosial bagi seluruh rakyat Indonesia, dari rumusan tersebut dengan adanya redaksi kalimat “...serta dengan mewujudkan suatu...” nampak bahwa keadilan sosial dirumuskan tidak hanya bersifat abstrak-filosofis, namun lebih bersifat kongkrit, selain itu keadilan sosial bukan hanya sebagai subjek hukum yang bersifat final dan statis namun merupakan suatu cita-cita yang harus diwujudkan secara dinamis, nampak sekali bahwa pendiri Negara menginginkan sebuah kerja nyata, dan effort maksimal bagi generasi penerus bangsa untuk mewujudkan cita-cita keadilan sosial (Asshiddiqie, 2011).

Untuk lebih mempertajam analisis tentang keadilan sosial, relefan untuk diketengahkan sebuah prinsip keadilan ekonomi yang dikemukakan oleh Louis Kelso dan Mortimer Adler, terdapat tiga prinsip yang bersifat interdependen, yaitu (1) Partisipasi, (2) Distribusi, (3) Harmoni, ketiganya menopang bangunan keadilan ekonomi dalam masyarakat, jika salah satunya diabaikan maka bangunan keadilan ini menjadi runtuh. Dalam prinsip partisipasi membuka kesempatan yang sama bagi setiap orang untuk berpartisipasi (equal oportunity) dalam proses produksi, dalam pengertian ini tidak boleh ada diskriminasi dalam membuka akses keterlibatan setiap orang dalam proses produksi baik dengan menginvestasikan modal (as a owner) maupun investasi potensi dan kemampuaan (as a worker), karena itu prinsip partisipasi ini menolak adanya monopoli, hak-hak khusus, dan rintangan-rintangan yang bersifat ekslusif dan sejenisnya. 
Bila prinsip partisipasi menekankankan pada keterlibatan setiap orang untuk berpartisipasi (input) maka pada prinsip distribusi mennekankan pada hasil (output) yang diperoleh dari sistem ekonomi bagi setiap orang/pekerja/buruh (worker) dan bagi setiap capital (owner). Dikemukakan oleh Louis Kelso \& Mourtimer adler bahwa keadilan distributif (distibutive justice) secara otomatis terkait dan harus terkait secara berimbang dengan keadilan partisipatif (partisipatif justice), dan pendapatan menjadi terkait dengan peran serta dalam proses produksi (productive constributions). Dalam prinsip distribusi ini menekankan bahwa keadilan dalam hal distribusi hasil produksi adalah sesuai dengan seberapa besar kontribusinya (to each according to his constribution). Menurut Louis Kelso \& Mourtimer Adler besarnya distribusi output bagi masing-masing orang/pekerja/buruh haruslah sesuai dengan kontribusi yang diberikan bagi jalannya proses produksi, dengan demikian prinsip distribusi ini menekankan pada bekerjanya sistem pasar bebas dan terbuka (free and open marketplace), prinsip partisipasi dan distribusi yang dikemukakan oleh Kelso dan Adler ini nampak sejalan dengan teori keadilan komutatif dan keadilan distributif yang dikemukakan oleh Aristoteles.

Prinsip partisipasi dan distribusi yang dikemukakan oleh Kelso dan Adler masih terlalu liberal untuk diterapkan di Indonesia yang memegang teguh Keadilan Sosial. Bagaimanapun bekerjanya sistem pasar secara bebas dengan seminimal mungkin campur tangan pemerintah justru dapat menimbulkan distorsi dan akan menciptakan ketidakadilan yang baru. Sebagaimana yang dikemukakan oleh Joseph Stieglitz bahwa selalu ada asymetrical information dalam mekanisme kerja pasar bebas yang menyebabkan kebebasan itu sendiri menjadi tidak adil dalam dirinya sendiri, oleh sebab itu intervensi Negara dalam proses produksi juga sangat diperlukan, karena disisi lain prinsip keadilan sosial tidak bisa mengesampingkan adanya pihak-pihak dalam Negara yang tidak mampu memberikan kontribusi maksimal terhadap proses produksi, bahkan sama sekali tidak berkontribusi sama sekali, golongan ini biasa disebut sebagai masyarakat yang kurang beruntung/dirugikan (disadvantage people). Disadvantage people ini adalah kelompok orang yang memiliki keterbatasan, seperti orang-orang cacat (disable people) - baik fisik maupun mental - orang tua renta, wanita-wanita yang mengurus anak-anak, dan orang-orang miskin yang tidak memiliki kemampuan untuk mengenyam pendidikan tinggi, sehingga terciptalah kemiskinan struktural. Kelompok disadvantage people ini akan terus menjadi kelompok yang termaginalkan oleh sistem pasar bebas (free and open marketplace)

Dengan hanya berpedoman pada dua prinsip tersebut (partisipasi dan distribusi) maka tidak dapat memenuhi kebutuhan keadilan sosial, untuk mengeleminir distorsi tersebut maka Kelso dan Adler mengemukakan prinsip ke-3 yaitu harmoni yang membutuhkan peran serta Negara secara seimbang. Kelso dan Adler mengemukakan konsep charity yang menyangkut ide "bagi semua sesuai kebutuhannya" (to each according to is needs), prinsip harmoni ini merupakan prinsip penyeimbang yang sangat diperlukan untuk mengatasi distorsi baik dalam input maupun output dan melakukan koreksi yang diperlukan untuk memulihkan tata ekonomi yang adil dan seimbang (justice for all).

Perlindungan terhadap pekerja dimaksudkan untuk menjamin hak-hak dasar dan menjamin kesamaan kesempatan serta perlakuan tanpa diskriminasi atas dasar apapun untuk mewujudkan kesejahteraan pekerja/buruh beserta keluarganya, beberapa aspek perlindungan pekerja, beberapa aspek perlindungan ketenagakerjaan antara lain adalah: (1) Keselamatan dan Kesehatan Kerja; dan (2) Jaminan Sosial Tenaga Kerja. Perlindungan pekerja tersebut hanya dapat tercapai jika adanya peran serta Negara secara aktif dalam menjaga stabilitas 
iklim industrialisasi dengan perindungan terhadap pekerja, atau dengan kata lain ditengah gesekan perubahan zaman dan menggeliatnya pertumbuhan ekonomi maka peran serta Negara merupakan keniscayaan.

Peran serta Negara secara aktif sebagai penyeimbang hanya dapat dijalankan oleh Negara kesejateraan (welfarestate) yang dijabarkan didalam black's law dictionary : welfare state a nation in which the government undertakes various social insurance programs, sunch as unemployment compentation, old age pensions, family allowances, food stamps, and aid to the blind or deaf - also termed welfafre - regulatory state, Negara kesejahteraan adalah suatu bangsa yang pemerintahannya menjalankan berbagai program asuransi sosial, seperti kompensasi pengangguran, pensiun, bantuan uang untuk keluarga, kupon makanan, dan bantuan bagi orang buta atau tuli juga pengertian kesejahteraan Negara sebagai pengatur.

Negara Republik Indonesia menganut paradigma Negara kesejahteraan (welfarestate) sebagaimana tercermin didalam UUD NRI 1945 khususnya ketentuan pasal-pasal sebagai berikut:

1. Pasal $28 \mathrm{H}$ ayat (1) : setiap orang berhak hidup sejahtera lahir dan batin, bertempat tinggal, dan mendapatkan lingkungan hidup yang baik dan sehat, serta berhak memperoleh pelayanan kesehatan

2. Pasal $28 \mathrm{H}$ ayat (3) : setiap orang berhak atas jaminan sosial yang memungkinkan pengembangan dirinya secara utuh sebagai manusia bermartabat

3. Pasal 28I ayat (2) : setiap orang bebas dari perlakukan yang bersifat diskriminatif atas dasar apapun dan berhak mendapatkan perlindungan terhadap perlakukan yang bersifat diskriminatif itu

4. Pasal 28I ayat (4) : Perlindungan, Pemajuan, Penegakan, dan pemenuhan Hak Asasi Manusia adalah tanggung jawab Negara, terutama pemerintah.

Kedudukan hukum antara pekerja/buruh dengan pengusaha seyogyanya harus setara, sebagaimana halnya hubungan hukum lainnya. Karena kedudukan keduanya sebagai subjek hukum yakni pendukung hak dan kewajiban. Karena kedudukannya setara maka tidak dibenarkan terjadi hubungan yang inferior antara satu dengan yang lainnya, karena pengusaha bukan merupakan atasan dari pekerja/buruh namun kedudukan keduanya sebagai mitra yang saling membutuhkan, karena yang dijadikan sebagai objek perjanjian adalah potensi/kemampuan yang dimiliki oleh buruh/pekerja dan upah yang layak bagi buruh/pekerja. Namun banyak terjadi dalam praktek hubungan kerja antara pekerja/buruh dengan pengusaha justru menempatkan pengusaha determinan atas pekerja/buruh. Ini disebabkan bekerja sistem pasar bebas (free and open marketplace), untuk mengeleminir terjadinya distorsi maka disinilah diperlukan konsep keadilan sosial (social justice) yang memang tidak selalu identik dengan keadilan ekonomi, politik, bahkan keadilan hukum, namun diujung pemikiran dan impian-impian tentang keadilan itu adalah keadilan sosial yang nyata, karena keadilan sosial merupakan simpul dari semua dimensi dan ide kemanusiaan tentang keadilan.

Keadilan sosial yang membungkus semua keadilan, dan mengatasi ketidakadilan yang timbul dari masing-masing ide tentang keadilan. Keadilan sosial berbeda dengan keadilan hukum yang terkadaang dipaksakan berlakunya, yang dalam perwujudannya haruslah melibatkan tiga ranah kekuasaan yakni, Negara (state), masyarakat (civil society), dan kekuatan pasas (market), secara bersama-sama, yang pengendali utamanya adalah Negara yang dimanifestasikan kepada pemerintah yang berdaulat yang mendapay mandat dari seluruh 
rakyat yang bertindak selaku dirigent untuk menyelenggarakan kekuasaan, pesan perlindungan terhadap pekerja/buruh merupakan pesan konstitusional yang dibebankan kepada Negara untuk mewujudkannya, sesuai dengan cita-cita mewujudkan kesejahteraan umum, dan mewujudkan masyarakat Indonesia seeutuhnya sesuai dengan Pancasila dan UUD NRI 1945 .

\section{B. Bentuk Perlindungan Hukum Bagi Pekerja}

\section{Hubungan Industrial}

Landasan sistem hubungan industrial di Indonesia adalah Pancasila dan UUD 1945 dengan ciri para pihak yang terlibat dalam hubungan industrial tersebut dipandang sebagai manusia yang bermartabat dan sederajat yang mudah melakukan komunikasi, koordinasi, konsultasi, sehingga setiap permasalahan sekecil apapun dapat diantisipasi, setiap perbedaan pendapat dapat diselesaikan dengan mudah dengan jalan musyawarah mufakat, dan mogok atau penutupan perusahaan (lock out) tidak pernah digunakan. Ciri-ciri sistem hubungan industrial tersebut akan dapat terlaksana dan terwujud bila ada peran serta dari pihak pemerintah, pengusaha, serikat buruh/serikat pekerja sesuai fungsi, posisi, penanan, hak dan kewajibannya masing-masing (Zulkarnaen, 2016).

Pasal 1 ayat (16) dikemukakan bahwa yang dimaksud dengan Hubungan Idustrial adalah suatu sistem hubungan yang terbentuk antara pelaku dalam proses produksi barang dan/atau jasa yang terdiri dari unsur pengusaha, pekerja/buruh, dan pemerintah yang didasarkan pada nilai-nilai Pancasila dan UUD NRI 1945 Pengusaha adalah :

a. Orang perseorangan, persekutuan, atau badan hukum yang menjalankan suatu perusahaan milik sendiri

b. Orang perseorangan, persekutuan, atau badan hukum yang secara berdiri sendiri menjalankan perusahaan bukan miliknya

c. Orang perseorangan, persekutuan, atau badan hukum yang berada di Indonesia mewakili perusahaan sebagaimana dimaksud dalam huruf a dan b yang berkedudukan di luar wilayah Indonesia

Pengusaha merupakan satu bagian dari pemberik kerja. Pemberi kerja adalah orang perseroangan, pengusaha, badan hukum, atau badan-badan lainnya yang mempekerjakan tenaga kerja dengan membayar upah atau imbalan dalam bentuk lain. Secara formal pengertian "pekerja" sama dengan "buruh" yakni setiap orang yang bekerja dngan menerima upah atau imbalan dalam bentuk lain, sedangkan pengertian pegawai sering digunakan untuk orang yang bekerja di pemerintahan, sehingga mereka disebut Pegawai Negeri. Pemerintah adalah organisasi yang memiliki kekuasaan untuk membuat dan menerapkan hukum serta undang-undang. Dalam melaksanakan fungsinya dalam hubungan industrial, pemerintah mempunyai fungsi menetapkan kebijakan, memberikan pelayanan, melaksanakan pengawasan, dan melakukaan penindakan terhadap pelanggaran UU Ketenagakerjaan, adapun hubungan industrial dilaksanakan melalui sarana :

a. Serikat Pekerja/Serikat Buruh

b. Organisasi Pengusaha

c. Lembaga Kerjasama Bipartit

d. Lembaga Kerjasama Tripartit

e. Peraturan Perusahaan

f. Perjanjian Kerja Bersama 
g. Peraturan Perundang-Undangan Ketenagakerjaan, dan

h. Lembaga Penyelesaian Perselisihan Hubungan Industrial

\section{Peradilan Hubungan Industrial}

Sesuai dengan tata hukum di Indonesia Pasal 1 angka I Nomor 2 Tahun 2004 memberikan pengertian tentang perselisihan hubungan industrial. Perselisihan Hubungan Industrial adalah perbedaan pendapat yang mengakibatkan pertentangan antara pengusaha atau gabungan pengusaha dengan pekerja/buruh atau serikat pekerja/serikat buruh karena adanya perselisihan mengenai hak, perselisihan kepentingan, perselisihan pemutusan hubungan kerja dan perselisihan antar serikat pekerja/serikat buruh dalam satu perusahaan. Dari pengertian di atas maka semakin jelas bahwa perselisihan hubungan industrial meliputi perselisihan hak, perselisihan antar serikat pekerja dalam satu perusahaan (Yunarko, 2011).

Dalam perkara perselisihan hubungan industrial, oleh Undang- Undang No. 2 tahun 2004 tentang Penyelesaian Perselisihan Hubungan Industrial (UUPPHI) telah ditetapkan tata cara dan proses penyelesaian Perselisihan Hubungan Industrial. Penyelesaian diluar pengadilan merupakan tahapan penyelesaian yang bersifat wajib (Pradima, 2013).

Perselisihan hubungan industriaal meliputi : (1) Perselisihan Hak; (2) Perselisihan Kepentingan; (3) Perselisihan Pemutusan Hubungan Kerja; (4) Perselisihan Antar Serikat Pekerja/Serikat Buruh hanya dalam satu perusahaan. Perselisihan hubungan industrial adalah perbedaan pendapat yang mengakibatkan pertentanga antara pengusaha atau gabungan pengusaha dengan pekerja/buruh atau serikat pekerja/serikat buruh karena adanya perselisihan mengenai hak, kepentingan, pemutusan hubungan kerja, dan perselisihan antar serikat pekerja/serikat buruh dalam satu perusahaan. Adapun prosedur penyelesaian perselisihan hubungan industrial adalah :

Pertama: penyelesaian melalui Perundingan bipartit, yang merupakan perundingan antara pekerja/buruh atau serikat pekerja/buruh dengan pengusaha untuk menyelesaikan perselisihan hubungan industrial. Penyelesaian melalui perundingan bipartit harus diupayakan semaksimal mungkin dengan cara musyawaran untuk mencapai mufakat. Kedua: jika perundingan bipartit tidak mencapai kesepakatan/mufakat maka jalan berikutnya adalah dengan melalui mediasi hubungan industrial yang merupakan penyelesaian perselisihan hak, perselisihan kepentingan, perselisihan pemutusan hubungan kerja, dan perselisihan antara serikat pekerja/buruh hanya dalam satu perusahaan melalui musyawarah yang ditengahi/mediasi oleh seorang atau lebih mediator yang netral, yang merupakan pegawai instansi pemerintah yang bertanggung jawab dibidang ketenagakerjaan yang memenuhi syarat-syarat sebagai mediator yang ditetapkan oleh Menteri.

Ketiga: jika tidak terjadi kesepakatan setelah dimediasi oleh mediator, masih ada jalana keluar penyelesaian perselisihan secara non litigasi yakni melalui arbitrase hubungan industrial, yang merupakan penyelesaian suatu perselisihan kepentingan, dan perselisihan antar serikat pekerja/buruh hanya dalam satu perusahaan, diluar peradilan hubungan industrial melalui kesepakatan tertulis dari para pihak yang berselisih untuk menyerahkan penyelesaian perselisihan kepada arbiter yang putusannya mengikat para pihak dan bersifat final. Keempat: melalui Pengadilan Hubungan Industrial yang merupakan pengadilan khusus yang dibentuk dilingkungan Pengadilan Negeri yang berwenang memeriksa, mengadili, dan memberi putusan terhadap perselisihan hubungan industrial. 
Perselisihan hubungan industriaal meliputi : (1) Perselisihan Hak; (2) Perselisihan Kepentingan; (3) Perselisihan Pemutusan Hubungan Kerja; (4) Perselisihan Antar Serikat Pekerja/Serikat Buruh hanya dalam satu perusahaan. Perselisihan hubungan industrial adalah perbedaan pendapat yang mengakibatkan pertentanga antara pengusaha atau gabungan pengusaha dengan pekerja/buruh atau serikat pekerja/serikat buruh karena adanya perselisihan mengenai hak, kepentingan, pemutusan hubungan kerja, dan perselisihan antar serikat pekerja/serikat buruh dalam satu perusahaan. Adapun prosedur penyelesaian perselisihan hubungan industrial adalah (1) Perundingan Bipartit; (2) Mediator; (3) Arbitrase; dan terakhir Perdilan Khusus Hubungan Industrial.

Penyelesaian perselisihan hubungan industrial dapat diwujudkan bila didukung oleh sistem mekanisme yang baik, yaitu bila kebenaran normatif dan kebenaran empiris telah dapat diwujudkan dalam sistem hukum ketenagakerjaan (Fatimah, 2015). Nyatanya keadilan dalam penyelesaian ini dihadapkan banyak kendala, penyebab sulitnya mewujudkan perlindungan terhadap pekerja. Secara umum persoalan perburuhan lebih banyak di identikan dengan perosalan antara pekerja dengan pengusaha.Pemahaman demikian juga dipahami sebagian besar para pemgambil kebijakan perburuhan sehingga terjadi redukksi pemahaman terhadap buruh sebagai pekerja dan buruh sebagai suatu profesi dan kategori sosial.Pemahaman tersebut mengakibatkan perlindungan terhadap pekerja/buruh menjadi sangat lemah.

\section{KESIMPULAN}

Perlindungan hukum terhadap pekerja dimaksudkan untuk menjamin hak-hak dasar dan menjamin kesamaan kesempatan serta perlakuan tanpa diskriminasi atas dasar apapun untuk mewujudkan kesejahteraan pekerja beserta keluarganya, beberapa aspek perlindungan pekerja, beberapa aspek perlindungan ketenagakerjaan antara lain adalah : (1) Keselamatan dan Kesehatan Kerja; dan (2) Jaminan Sosial Tenaga Kerja. Perlindungan pekerja tersebut hanya dapat tercapai jika adanya peran serta Negara secara aktif dalam menjaga stabilitas iklim industrialisasi dengan perindungan terhadap pekerja, atau dengan kata lain ditengah gesekan perubahan zaman dan menggeliatnya pertumbuhan ekonomi maka peran serta Negara merupakan keniscayaan.

\section{DAFTAR PUSTAKA}

Ahmad, J. (2018). Desain penelitian analisis isi (Content analysis). Research Gate, 5, 1-20.

Anzar, A. (2020). Perlindungan Hukum Terhadap Pekerja Alih Daya (Outsourcing). TOMAKAKA LAW REVIEW (TOLREV), 1(1 Mei), 66-83

Asshiddiqie, J. (2011). Pesan Konstitusional Keadilan Sosial. Makalah, Malang, 12.

Budiartha, I. (2016). HUKUM OUTSOURCING: Konsep Alih Daya, Bentuk Perlindungan, dan Kepastian Hukum, Jakarta: Setara Press.

Charda, S. (2015). Karakteristik Undang-Undang Ketenagakerjaan Dalam Perlindungan Hukum Terhadap Tenaga Kerja. Jurnal Wawasan Yuridika, 32(1), 1-21.

Fatimah, Y. N. (2015). Penyelesaian Perselisihan Hubungan Industrial di Pengadilan Hubungan Industrial dalam Pemenuhan Hak Pekerja/Buruh Yang di Putus Hubungan Kerja. Pandecta: Jurnal Penelitian Ilmu Hukum (Research Law Journal), 10(2), 215-232. 
Hendrastomo, G. (2010). Menakar kesejahteraan buruh: memperjuangkan kesejahteraan buruh diantara kepentingan negara dan korporasi. Jurnal Informasi, 16(2), 1-16.

Pradima, A. (2013). Alternatif Penyelesaian Perselisihan Hubungan Industrial di Luar Pengadilan. DiH: Jurnal Ilmu Hukum, 9(17), 1-18.

Qamar, N., \& Djanggih, H. (2017). Peranan Bahasa Hukum dalam Perumusan Norma Perundang-undangan. Jurnal Ilmiah Kebijakan Hukum, 11(3), 337-347.

Singadimedja, H. N. (2020). Resensi Buku: Hukum Ketenagakerjaan: Hakikat Cita Keadilan Dalam Sistem Ketenagakerjaan. Jurnal Bina Mulia Hukum, 4(2), 369-379.

Statistik, B. P. (2019). Februari 2019: Tingkat Pengangguran Terbuka (TPT) sebesar 5, o1 persen. Online [https://www. bps. go. id/pressrelease/2019/05/06/1564/februari-2019-tingkat-pengangguran-terbuka--tpt--sebesar-5-o1-persen. html].

Saefuloh, A. A. (2011). Kebijakan Outsourcing di Indonesia: Perkembangan dan Permasalahan. Jurnal Ekonomi E Kebijakan Publik, 2(1), 337-369.

Suhardin, Y. (2012). Peranan Negara Dan Hukum Dalam Memberantas Kemiskinan Dengan Mewujudkan Kesejahteraan Umum. Jurnal Hukum \& Pembangunan, 42(3), 302-317.

Suyanto, H., \& Nugroho, A. A. (2017). Perlindungan Hukum terhadap Hak-hak Pekerja Outsourcing Berdasarkan Asas Keadilan. Jurnal Yuridis, 3(2), 61-74.

Yunarko, B. (2011). Penyelesaian Perselisihan Hubungan Industrial Melalui Lembaga Arbitrase Hubungan Industrial. Perspektif, 16(1), 52-58.

Zulkarnaen, A. H. (2016). Perlindungan Hukum Terhadap Pekerja Dalam Pelaksanaan Hubungan Industrial. Padjadjaran Journal of Law, 3(2), 407-427. 